\title{
The Effect of Learning Cycle Model Assisted by Self-Assessment on Students' Writing Competency at EFL Students in SMP Saraswati 1 Denpasar
}

\section{Candra Dewi I.G.A.A.I.R*}

Universitas Pendidikan Ganesha

\section{A R T I C L E I N F 0 \\ Article history: \\ Received 29 December 2019 \\ Received in revised \\ Form 01 January 2020 \\ Accepted 18 January \\ 2020 \\ Available online 28 \\ February 2020}

Keywords:

Learning cycle model

assisted by self-

assessment, Writing

competency

\section{A B S T R A C T}

This study aimed to investigate the implementation and the effect of learning cycle model assisted by self-assessment on the eighth grade students in SMP Saraswati 1 Denpasar in the academic year 2018/2019. The population was 294 students. The sample was 82 students selected by using a random sampling technique. This research used a mixed method design. The quantitative design used a posttestonly control group design and the qualitative design used descriptive qualitative design. The result of the t-test showed that the sig. ( 2 tailed) value was $0.000 \leq 0,05$. The mean score of the experimental group was 88.20 and the control group was 79.12. It can be concluded that writing competency of the experimental group was higher than the control group. This result was justified by the result of the observation checklist which showed that the implementation of learning cycle model assisted by self-assessment was very good. 


\section{Introduction}

In junior high school, students need to learn English as a foreign language. English is an important subject to learn as one of the subjects that are tested in the national examination. The learning process can be defined as a reflective process that enables the learner to learn by the previous experience. It means that the learners learn more about something based on their past experiences.

There are some components in an effective teaching, such as (a). a good material corresponding with the syllabus, which means that the teacher chooses the appropriate material corresponding with the syllabus used. (b). a good teaching technique: the teaching technique employed should be appropriate to the material used and students' need 'and (c) the students' feeling in the teaching-learning process: to make the teaching and learning process more effective, the teaching and learning process should be enjoyable and make the students comfortable in following the learning process.

There are some components in an effective teaching, such as (a). a good material corresponding with the syllabus, which means that the teacher chooses the appropriate material corresponding with the syllabus used. (b). a good teaching technique: the teaching technique employed should be appropriate to the material used and students' need 'and (c) the students' feeling in the teaching-learning process: to make the teaching and learning process more effective, the teaching and learning process should be enjoyable and make the students comfortable in following the learning process.

Writing is the most important skill to learn and should be mastered by the learner (Hyland, 2003). It means that the learners need to develop their writing skill well. There are five steps in writing process (Oshima \& Hogue, 1997). The five steps are: (a). pre-writing: is a way to get ideas, (b). organizing: organize the ideas into a simple outline, (c). writing: write a draft and use the outline as guidance, (d). revising and editing: polish what did you have written, and (e). Final writing: write the final writing.

According to Nezakatgoo (2011), writing skill is difficult for the English foreign language learners to be master. Several problems in writing usually occur to beginner students. They usually find difficulty in the learning process. The problems are ideas development and how to organize them into a good essay. Although some of them can write, they are often confused and face difficulties in grammar, vocabulary, and use of punctuations when they are writing.

Grossman (2009) states that the difficulties in writing are caused by two important factors. The factors are linguistic problems and limitation in writing skills. The problems cause the students to have a low writing achievement. To solve these problems it is important for the teacher to choose a good technique in teaching writing.

In the 2013 Curriculum the teaching and learning process is expected to be able to achieve the learning objective. But, in fact, it cannot be realized well because of the teachers' habit of using conventional teaching at every meeting. Some teaching techniques can be used, especially in teaching writing. Cash, Ravenel, \& Cash. (2014) state that in the EFL context, the teacher should optimize the learning process by using teaching techniques. One of the teaching techniques is learning cycle model.

The learning cycle model is a set of learning cycles which consist of several important steps or phases that should be followed by the teacher and the students in the teaching and learning process. Based on the explanations above, the researcher used a learning cycle model by Hyland (2003). The learning cycle model includes the four language skills : speaking, listening, reading and writing. There are three steps in applying the learning cycle model in the teaching and learning process (Hyland, 2003). The three phases are (a) modeling a text, (b) joint construction of a text and (d) independent construction of a text.

According to Hyland (2008), learning cycle model makes the students more easier in writing process because every process is very structured and purposed to make the students can write independently. The learning cycle model has been implemented in some schools in Indonesia such as in Bali. One of the schools that have used this teaching technique is SMP Saraswati 1 Denpasar.

The implementation of the learning cycle model is done is not yet clear, especially at the eighth grade in SMP Saraswati 1 Denpasar. If it is less effective it means that the implementation of the learning cycle model should be made more optimal.

To maximize the use of the learning cycle model in the learning process it was assisted by selfassessment. Therefore, the researcher combined the learning cycle model and self-assessment. The selection of self-assessment was based on the Government Regulation No. 19 of 2005 about National Education Standard (Presiden RI, 2005). The assessment can be used as a proof of whether or not the learning objectives are achieved. Therefore, an assessment should be done continuously and should not only be made in the final part of the teaching what the teacher did at the eighth class in SMP Saraswati Denpasar. The researcher was interested to choose self-assessment because this assessment is continuously oriented to the learning process and the result (product). 
Based on this research, the researcher used the learning cycle model adopted from Hyland (2003). According to Hyland (2008), learning cycle model makes it easier for the students to write because every process is very structured and is aimed to make the students be able to write independently. The use of the learning cycle model also helps the students to improve their writing competency independently (Dirgeyasa, 2016).

Self-assessment is an assessment done by the students themselves to compare their relative position with the criteria which have been specified (Permendikbud No.66 year 2003). The combination of the learning cycle model with self-assessment is expected to be effective in improving the writing competency of the students. By using the learning cycle model assisted by self-assessment, the students are expected to learn step by step corresponding with the cycles.

Meanwhile, this research aimed to observe the implementation of the learning cycle model assisted by self-assessment and to measure the effect of the learning cycle model assisted by self-assessment for the EFL students in SMP Saraswati 1 Denpasar. The combination of the learning cycle model and selfassessment is effective in the teaching and learning process, especially in writing class.

Qarareh (2017) did a research on the effect of using the learning cycle method in teaching science on the educational achievement of the six graders. The result showed that the learning cycle method was very good to use in the education field and the other subjects.

Then, Hanuscin \& Lee (2008) did a research on using learning cycle as a model for teaching and learning cycle to preservice elementary teacher. The findings showed that the concept of learning cycle model could help the teacher in conducting the teaching and learning process, and the learning cycle model also made the learning process more interesting and could develop the students' achievement in a writing activity.

Jumarah et al. (2013) did a research on the effect of self-assessment and self-concept on the students' writing competency at eighth grade of MTS Darul Aitam Jerowaru in academic year 2012/2013. The researcher looked at the effect of self-assessment only and the finding of this research showed that there was a significant effect of self-assessment on the students' writing competency.

\section{Methods}

This research used a mixed-method research design because it involved a quantitative research design and qualitative research design. The mixed-method research design is an explanatory sequential mixed method design. Creswell (2013) states that the mixed-method research design involves the combination of qualitative and quantitative research data in a research study.

A quantitative research is conducted and the results were analyzed. The results then are explained in more detail qualitatively It is considered to be explanatory because the initial quantitative data results are explained further with the qualitative data (Creswell, 2013). The result of the quantitative data analysis was justified by the result of qualitative data.

The quantitative research tests objective theories by examining the relationship among variables. These variables are measured by numeric data and analyzed by using statistical procedures (Creswell, 2013). The present study used a posttest-only control group design. According to Cohen (2018), in the posttest-only control group design, there is no pretest. Therefore, the mean score of the experimental group is compared with that of the control group. the experiment group was treated by the learning cycle model assisted by self-assessment and the control group by conventional teaching

The qualitative research explores the meaning individuals or groups ascribed to a social or human problem (Creswell, 2013). The qualitative research is descriptive qualitative research which describes the phenomenon based on the fact in real life. The qualitative data are collected from the result of the observation during treatment. The result of qualitative data justifies the result of quantitative data so that the result of this research is very accurate.

The population of this research was the EFL Students of the eighth grade students in SMP Saraswati 1 Denpasar in the academic year 2018/2019. The total number of the population was 294 students from seven classes.

There were some steps to determined the sample of this research. The first step was checking the normality of the data by using IBM SPSS Statistic 22 with the students' score taken from the last test that was administered by the school before. The result of the normality test showed that the EFL Students of SMP Saraswati 1 Denpasar especially the eighth-grade students which consist of seven classes were had a normal distribution.

The second step was determining two classes as the sample. The two classes selected from the seven classes. The sample was selected by lottery. It is attempted to decide two groups of the sample such 
as the experimental group and control group. The research found two classes as the sample. The sample was VIII A class and VIII F class.

The third was checking the homogeneity data from the sample by using Levene Statistic test. The result shows that the writing competency of the sample was homogenous. The sig. value of the VIII A class and VIIIF class was 0.082 (sig. value $\geq 0.05$ ). Finally, the experimental and control groups were selected from the sample. The researcher used a lottery. The result of the lottery showed that classVIII A was the experimental group and class VIII F the control group.

There were two variables used, independent variable and dependent variables. The learning cycle model assisted by self-assessment was the independent variable. And writing competency was the dependent variable. The learning cycle model assisted by self-assessment is a combination of the learning cycle model and self-assessment.

The instruments for treatment were the instruments used in the implemented learning cycle model assisted by self-assessment for the experimental group only. The research instruments used were the lesson plan and an observation checklist.

The instruments for treatment were the instruments used in the implementation of learning cycle model assisted by self-assessment for the experimental group only. The research instruments used was an observation checklist to observe the implementation of learning cycle model assisted by self-assessment in the classroom.

The instruments for data collection were writing test for posttest and writing scoring rubric. The test can be defined as a type of assignment which was used in the posttest. The researcher used the writing scoring rubric as the research instrument to collected the data. The writing scoring rubric was adopted from Marhaeni (2005).

The researcher used two types of data analysis, namely descriptive analysis and inferential statistics analysis. The descriptive analysis measured the central tendency including medium, mean, mode and the standard deviation.

The inferential statistical analysis can be defined as the way to make the complete conclusion beyond the data observed. Based on this research, the researcher uses T-Test as the parametric statistic test of this research. Before analyzing the data, the researcher should analysis the normality and homogeneity of the variance.

The normality testing was conducted by using Kolmogorov and Smirnov. the result of the Kolmogorov-Smirnov formula showed that the Asymp. Sig. (2-tailed) value of A1Y1 = 0,115 and A2Y1 = 0,102 . Therefore, the result showed Asymp. Sig. (2-tailed) The value of each group was higher than $\alpha=$ $0.05(5 \%)$, so the data were categorized had a normal distribution.

The homogeneity testing was done by Levene Statistic formula assisted by IBM. SPSS. 22. The sig. value was higher than $\alpha=0.05(5 \%)$, the sig. value was 0.361 . It means that the data varience were homogenous.

This research was used t-test formula to analyze the data and get the result for hypothesis testing. The purpose of using t-test formula because this research had two groups as the sample and also purposed to find out the effect of The Learning Cycle model Assisted by Self-Assessment on writing competency of the eighth grade students in SMP Saraswati 1 Denpasar.The result of the t-test the formula showed that the Sig. (2-tailed) value was 0,000. The result was smaller than $\alpha=0.05(5 \%)$..

\section{Result And Discussion}

Based on the quantittive analysis data, the Sig. (2-tailed) value was 0,000. It means that H0 was rejected. There was a significant effect on the students who were treated by using Learning Cycle Model assisted by Self-Assessment.

Based on the descriptive data, the mean score of the experimental group was 88.20 and the mean score of the control group was 79.12. It indicates that the writing competency of the students who were treated by learning cycle model assisted by self-assessment was better than the writing competency of the students who were treated by conventional teaching. This fact shows that the use of learning cycle model assisted by self-assessment improved the students' writing competency in SMP Saraswati 1 Denpasar. The quantitative result was proven by the result of the qualitative data which were obtained by an observation in 10 meetings.

The result of the observation shows that all items were practiced during the teaching and learning process. The findings show the implementation of the learning cycle model assisted by self-assessment was very good and also give a good effect on the students' writing competency.

This study found out that learning cycle model assisted by self-assessment affects the students' writing competency in the process of writing. The use of self-assessment gives a good effect on the 
students' learning achievement. The self- assessment can give a positive effect on the students' competency when this assessment is directly connected with the task (Ross, 2006). While they are writing and checking their works, the students analyze their works directly by using the self-assessment checklist. It makes the students think carefully and critically about their mistake before revised their own work.

Meanwhile, the use of self-assessment makes the students know the goal that has been achieved and that which has not yet been achieved in the learning process. According to Yoon \& Lee (2013), selfassessment gives a chance to the students to know their achievement and do an evaluation to correct the mistakes so that the result of the students' competency is better in learning English.

One of the features of self-assessment in learning cycle model assisted by self-assessment is that it can make the students monitor and check their own works when the students could know their strengths and weaknesses by using a self-assessment checklist. It helps the students improve their writing competency because in monitoring and checking their works, the students correct their mistakes before collecting their works to the teacher.

An authentic assessment in learning cycle model assisted by self-assessment supports the improvement of writing competency of the students because it is an ongoing process. The students' writing competency is improved by doing a lot of practice (Langan, 2010). Rolheiser \& Ross (in Marhaeni et al., 2017) state that self-assessment can give a good effect to the students, because by doing self-assessment, the students can get feedback for themselves based on their competence. Therefore, if the students evaluate their performance positively, self-assessment encourages them to set higher goals and effort for themselves.

Then, by focusing the self-assessment the students have to produce a better result of their product because the writing process is ongoing. From the result of the self-assessment, the students know their achievements based on their evaluation result. They write better than before as proven by their evaluation. In this case, the self-assessment encourages students to make decisions for themselves, not waiting for the teacher to tell their strengths and weaknesses but are able to decide their purposes for the next product as the self-reaction of their evaluation before (Black, 2003).

Moreover, by using self-assessment the students also begin to develop an overview of their works, it becomes possible for them to manage and control those works for themselves. Self-assessment makes the students begin to realize that revealing their problem is worthwhile, as the focus of teaching is to improve the competency rather than to compare one student with another (Black, 2003). This is the reason for the students to feel very interested and confident in following self-assessment.

The result of this research was also supported by previous research. The same research about the effect of the learning cycle model assisted by self-assessment on student's writing competency at EFL students was hardly found in the literature. The research about the effect of using the learning cycle method in the teaching process was conducted by Qarareh (2012) who investigated the effect of learning cycle method on teaching and learning process especially in the writing class.

The finding showed that the writing competency of the student was good after following the learning cycle method during the teaching and learning process. Qarareh's research supported this research because using learning cycle method during the treatment improved the writing competency of the students. The advantage of this research was using self-assessment.

The research about the effect of self-assessment from Somehoen (2013) investigates the implementation of self-assessment in writing intermediate EFL students at a university in Thailand. The finding showed that the writing competency of the students improved after doing self-assessment. The combination of the learning cycle model assisted by self-assessment was a new strategy that helps the students in improving their writing competency. Somehoen's research showed that self-assessment improves the writing competency of the students.

The research from Comert \& Kutlu (2018) who investigated the effect of self-assessment on achievement in writing also supports the finding of the present study. The finding of this research showed that writing lessons in which students practiced self-assessment were more effective in improving the writing skills of students than writing lessons conducted by traditional method. Comet's research supports this research because the use of self-assessment as the treatment improved the writing skill of the students. Self-assessment is powerful in improving writing skill of the students.

Another research that supports this research is the one conducted by Baleghizadeh \& Hajizadeh (2014) who investigated the self- and teacher-assessment in an EFL writing class. The result of the research showed that self-assessment could not only be viewed as a useful tool for evaluating learners' performance but also should be regarded as an efficient instrument for developing their writing skills. The use of self-assessment was very useful and powerful in improving the writing competency of the students. 
The relationship between the results of the hypothesis of this research with the previous research was using self-assessment. The result of this research showed that the writing competency of the EFL students in SMP Saraswati 1 Denpasar especially in eighth grade students improved after being treated by using the learning cycle model assisted by self-assessment. It means that the result of this research and the result of the previous studies support each other.

Based on the relationship between the results of this research with the previous research, it can be concluded that the use of self-assessment in teaching writing was very powerful. This fact was justified by the result of the writing competency of the EFL students in SMP Saraswati 1 Denpasar especially at the eighth grade students which were observed before. The finding shows that the use of self-assessment in the teaching and learning process is very powerful and has a good effect on the teacher and the students. This statement is proven by the result of the observation which showed the process has been implemented and observed well.

The result of the writing test of the students was calculated before and showed that the writing competency of the students' competency was successfully improved after being treated by using the learning cycle model assisted by self-assessment. It showed that the implementation of the learning cycle model assisted by self-assessment was very good. And the result of the data showed there was a significant effect on the students' writing competency of the EFL Students in SMP Saraswati 1 Denpasar.

Based on the result of the data analysis and the discussion, there were some conclusions of this research. The conclusions are as follows :

The implementation of the learning cycle model assisted by self-assessment was very good. The teacher and the students could follow the learning phases well. The researcher used an observation checklist to observe the teaching and learning process in the classroom. The researcher observed the experimental group only because only the experimental group which got the treatment by using the learning cycle model assisted by self-assessment.

The result of the observation conducted in the tenth meeting showed that the implementation of the learning cycle model assisted by self-assessment was very good. The teacher implemented this strategy well so that the students were very brave and interested in following the learning process, especially in writing activities. Started from the first meeting until the tenth meeting, the writing competency of the students remained good. It means that the implementation of the learning cycle model assisted by self-assessment is very successful in increasing the writing competency of the students.

There is an effect of the learning cycle model assisted by self-assessment on the eighth grade students in SMP Saraswati 1 Denpasar. There were two groups as the sample. The experimental group (A1Y1) who were treated by the learning cycle model assisted by self-assessment and the control group (A2Y1) who were treated by conventional strategy. The researcher investigated the effect of the learning cycle model assisted by self-assessment by using t-test formula. The Result of the $t$-test formula shows, the Sig. (2-tailed) value $=0,000$, so it was smaller than $\alpha=0.05(5 \%)$.

So the result of the hypothesis showed that the null hypothesis was rejected and the alternative hypothesis was accepted. It means that there was a significant effect of the students writing competency after treated by the learning cycle model assisted by self-assessment.

The result was justified by the result of the observation checklist which showed the total score was 5 , it means that the implementation of the learning cycle model assisted by self-assessment was very good and improved the writing competency of the students

\section{Conclussion}

Based on the result of the data analysis and the discussion, there were some conclusions of this research. The implementation of the learning cycle model assisted by self-assessment was very good. The teacher and the students could follow the learning phases well. The researcher used an observation checklist to observe the teaching and learning process in the classroom. The researcher observed the experimental group only because only the experimental group which got the treatment by using the learning cycle model assisted by self-assessment.

The result of the observation conducted in the tenth meeting showed that the implementation of the learning cycle model assisted by self-assessment was very good. The teacher implemented this strategy well so that the students were very brave and interested in following the learning process, especially in writing activities. Started from the first meeting until the tenth meeting, the writing competency of the students remained good. It means that the implementation of the learning cycle model assisted by self-assessment is very successful in increasing the writing competency of the students.

There is an effect of the learning cycle model assisted by self-assessment on the eighth grade students in SMP Saraswati 1 Denpasar. There were two groups as the sample. The experimental group 
(A1Y1) who were treated by the learning cycle model assisted by self-assessment and the control group (A2Y1) who were treated by conventional strategy. The researcher investigated the effect of the learning cycle model assisted by self-assessment by using t-test formula. The Result of the t-test formula shows, the Sig. (2-tailed) value $=0,000$, so it was smaller than $\alpha=0.05(5 \%)$.

So the result of the hypothesis showed that the null hypothesis was rejected and the alternative hypothesis was accepted. It means that there was a significant effect of the students writing competency after treated by the learning cycle model assisted by self-assessment.

The result was justified by the result of the observation checklist which showed the total score was 5 , it means that the implementation of the learning cycle model assisted by self-assessment was very good and improved the writing competency of the students.

\section{Reference}

Biggs, J. B. (1989). Higher Education Research \& Development Approaches to the Enhancement of Tertiary Teaching Approaches to the Enhancement of Tertiary Teaching. Higher Education Research and Development, 8(1). https://doi.org/10.1080/0729436890080102

Black, P. (2003). The nature and value of formative assessment for learning. Improving Schools, 6(3), 722. https://doi.org/10.1177/136548020300600304

Cash, J. W., Ravenel, S., \& Cash, J. W. (2014). Writing and Building, 2004. In Larry Brown (pp. 227-233). https://doi.org/10.14325/mississippi/9781604739800.003.0015

Cohen, L., \& Cohen, L. (2018). 109Research design. In Research Methods in Education (pp. 109-284). https://doi.org/10.4324/9781315456539-47

Comert, M., \& Kutlu, O. (2018). The Effect of Self-Assessment on Achievement in Writing in English. Journal of Educational Sciences Research, 8(1), 107-118. https://doi.org/10.22521/jesr.2018.81.4

Creswell, J. W. (2013). Research Design Qaulittive, Qantitative and Mixed Method Approach. In SAGE Publications, Inc (Vol. 91).

Crystal, D. (2003). English as a global language, second edition. In English as a Global Language, Second Edition. https://doi.org/10.1017/CB09780511486999.

Dirgeyasa, I. W. (2016). Genre-Based Approach: What and How to Teach and to Learn Writing. English Language Teaching, 9(9), 45. https://doi.org/10.5539/elt.v9n9p45

Grossman, J. H. (2009). Materialities of Writing. Novel: A Forum on Fiction, 39(1), 135-137. https://doi.org/10.1215/ddnov.039010135

Hanuscin, D. L., \& Lee, M. H. (2008). Using the learning cycle as a model for teaching the learning cycle to preservice elementary teachers. Journal of Elementary Science Education, 20(2), 51-66. https://doi.org/10.1007/bf03173670

Heritage, M., \& Heritage, J. (2013). Teacher Questioning: The Epicenter of Instruction and Assessment. Applied Measurement in https://doi.org/10.1080/08957347.2013.793190

Hyland, K. (2003). Genre-based pedagogies: A social response to process. Journal of Second Language Writing, 12(1), 17-29. https://doi.org/10.1016/S1060-3743(02)00124-8

Hyland, K. (2008). Genre and academic writing in the disciplines. Language Teaching, 41(4), 543-562. https://doi.org/10.1017/S0261444808005235

Langan, J. (2010). Exploring writing sentences and paragraph. In New York: Mc Graw Hill.

Marhaeni, A. A. I. N., Artini, P., Ratminingsih, M., Dewi, S., \& Kusuma, I. (2017). Asesmen Autentik dalam Pembelajaran Bahasa Inggris. Sigaraja: PT. Rajagrafindo Persada. 
Marhaeni, A. A. I. N., \& Dantes, N. (2013). the Effect of Self-Assessmentand Self-Concept on Students' Writing Competency At Eighth Grade of Mts Darul Aitam Jerowaruin Academic Year 2012/2013. 1.

Nezakatgoo, B. (2011). Portfolio as a Viable Alternative in Writing Assessment. Journal of Language Teaching and Research, 2(4). https://doi.org/10.4304/jltr.2.4.747-756

Oshima, A., \& Hogue, A. (1997). Introduction to Academic Writing: Second Edition. Agenda, 223. https://doi.org/10.1017/CB09781107415324.004

Presiden RI. Peraturan pemerintah Republik Indonesia Nomor 19 tahun 2005 tentang standar nasional pendidikan. , Peraturan pemerintah Republik Indonesia (2005).

Qarareh, A. 0. (2012). The Effect of Using the Learning Cycle Method in Teaching Science on the Educational Achievement of the Sixth Graders. 20-45. https://doi.org/10.1080./09751122.2012.11890035. 